\title{
SYNTHETIC POLYMERS ON WATER RETENTION AND PORE DISTRIBUITION IN A CLAYEY LATOSOL
}

\author{
Polímeros sintéticos na retenção de água e distribuição de poros em um Latossolo muito argiloso
}

Pedro Antônio Namorato Benevenute ${ }^{1 *}$; Lucas Ademir Carvalho Passos²; Laura Beatriz Batista de Melo ${ }^{3}$; Érika Andressa da Silva ${ }^{4}$; Geraldo César de Oliveira ${ }^{5}$

\begin{abstract}
${ }^{1}$ Agronomy Student; Soil Science Department; Federal University of Lavras - UFLA; benevenutepedro@gmail.com 2 Agricultural Engineering student; Soil Science Department; Federal University of Lavras - UFLA; lucasademir6@gmail.com ${ }^{3}$ Environmental Engineering Student; Soil Science Department; Federal University of Lavras - UFLA; lauramelo26@hotmail.com ${ }^{4}$ Doctoral Student in Soil Science; Soil Science Department; Federal University of Lavras - UFLA; andressaerikasilva@gmail.com

${ }^{5}$ Associate Professor; Soil Science Department; Federal University of Lavras - UFLA; geraldooliveira@dcs.ufla.br
\end{abstract}

Artigo enviado em 19/01/2017, aceito em 21/02/2017 e publicado em 03/03/2017

\begin{abstract}
The use of polymers is increasing at the agricultural area, however their effects on soil porosity have been little studied. The objective of this article is to analyze the effects of applied synthetic polymers on soil porosity and water retention of a Dystroferric Red Latosol. This study was conducted on undisturbed samples collected at a depth of $0.05 \mathrm{~m}$ in a Latosol beneath native forest. The samples were saturated with distilled water and polymers $\mathrm{HyC}, \mathrm{HyA}$, $\mathrm{HyB}$ diluted in water according to use recommendations for coffee plantations. These samples were then submitted to matric potentials of $-2,-4,-6$ and $-10 \mathrm{kPa}$ in the suction units and $-33,-100,-500$ and $-1500 \mathrm{kPa}$ in a Richards extractor. The models were fitted and pore size distribution estimates calculated. The data were subjected to variance analysis and the averages were compared using the Scott-knott test to a level of $5 \%$. Decreasing of large pores volume than $145 \mu \mathrm{m}$, was detected with the application of polymers HyA and B. However the HyB polymer promoted a reduction in the pore volume in the intermediate classes $(2.9-0.6 ; 0.6-0.2 \mu \mathrm{m})$, that are responsible for water availability to plants. On the other hand the $\mathrm{HyC}$ polymer promoted an increase in the soil water retention.
\end{abstract}

Keywords: soil porosity; synthetic polymers; soil water availability.

RESUMO: O uso de polímeros é crescente no meio agrícola, porém seus efeitos na porosidade do solo são pouco estudados. O presente trabalho teve como objetivo analisar os efeitos da aplicação de polímeros sintéticos na porosidade e retenção de água de um Latossolo Vermelho Distroférrico muito argiloso. O estudo foi realizado em amostras indeformadas coletadas na profundidade de $0,05 \mathrm{~m}$, em um Latossolo sob mata nativa. Amostras foram saturadas com água destilada e com os polímeros $\mathrm{HyC}, \mathrm{HyA}, \mathrm{HyB}$ diluídos em água conforme recomendações de uso para cultura do cafeeiro. Em seguida estas amostras de solos foram submetidas a potenciais matriciais de -2, -4, - 6 e $10 \mathrm{kPa}$ nas unidades de sucção e -33, -100, -500 e -1500 kPa nas câmaras de Richards. Foi realizada a modelagem de curvas de retenção de água e calculada a distribuição de poros por tamanho. Os dados foram submetidos a análises de variância e as médias comparadas pelo teste de Scott-knott ao nível de $5 \%$. Houve uma redução do volume de poros da classe de tamanho $>145 \mu \mathrm{m}$ quando o solo foi saturado com os polímeros HyA e HyB. O polímero HyB promoveu uma redução do volume de poros das classes intermediárias $(2,9-0,6 ; 0,6-0,2 \mu \mathrm{m})$, responsáveis pela disponibilidade de água para as plantas. Já o polímero HyC promoveu o aumento da retenção de água no solo.

Palavras-chave: porosidade do solo; polímeros sintéticos; disponibilidade de água no solo. 


\section{INTRODUCTION}

In the 80 's studies were undertakes that had the objective of using anionic polymers as soil conditioners, trying to achieve a sustainable agriculture that values more efficient water use (OLIVEIRA et al., 2004a; ALBUQUERQUE et al., 2009).

In this context, materials that have the ability to keep the water for a longer time in the soil that is called hydrogels or hydro absorbent polymers. When these polymers are hydrated, they turn into gel and can increase their own weight one hundred times more than their normal weight in water (AZEVEDO et al., 2002). Because of these characteristics, research has shown that hydrogels can promoted higher retention and gradual release of water through the soil, allowing more water availability to the plants (ZONTA et al., 2009; MARQUES et al., 2013; SANTOS et al., 2015).

In agriculture the application of hydro absorbent polymers in planting furrows to optimize plant water use has satisfactorily contributed to increase crop productivity, while minimizing irrigation costs (DEMARTELAERE et al., 2009, MARQUES; BASTOS 2010, CASTRO et al., 2014).

In some works with hydro absorbent polymers, Prevedello e Balena (2000) found that the dose of $32 \mathrm{~kg} \mathrm{~m}^{-3}$ can even double the water retention capacity of clay soils and increase this capability in sandy soils up to 7.5 times. Marques et al. (2013), studying the use of hydrogel as a substitute for irrigation of 'Iapar 59' coffeeseedlings, concluded that the use of hydroplan-EB ${ }^{\circledR}$ hydro absorbent, at a dose of $2 \mathrm{~g}$ per seedling, provided seedlings of the same quality as those which were irrigated.

Demartelaere et al. (2009) observed that the use of hydrogel polymer in Red Yellow Argisol reduced the amount of water used for irrigation of melon crops by $25 \%$. Lopes et al. (2010) evaluated the performance of Eucalyptus urograndis seedlings in clayey soil applying hydrogel, it was noted that the polymer enabled the successful development of the seedlings for about 37 days without additional irrigation.

Whereas Latosol has low retention capacity of plant extractable water and that such soils cover large expanses of the Cerrado region
(SILVA et al., 2015; SILVA et al., 2014) which is characterized by the occurrence of prolonged periods of drought (CARDUCCI et al., 2015), the study of practices that prioritize water saving is fundamental.

In the literature there are few studies that consider the evaluation of the hydrogel effects on Latosol porosity. As such, this study investigated the effects of synthetic polymer application on porosity and water retention of a Dystroferric Red Latosol.

\section{MATERIALS AND METHODS}

The soil material studied, classified as Dystroferric Red Latosol (Oxisol) very clayey (LVdf), according to particle size distribution (630 $\mathrm{g} \mathrm{kg}^{-1}$ Clay; $230 \mathrm{~g} \mathrm{~kg}^{-1}$ Silt; $140 \mathrm{~g} \mathrm{~kg}^{-1}$ Sand) and Brazilian Soil Classification System (EMBRAPA, 2013).

Twenty samples were collected at a depth from 0 to $0.05 \mathrm{~m}\left(650 \mathrm{~g} \mathrm{~kg}^{-1}\right.$ Clay; $210 \mathrm{~g} \mathrm{~kg}^{-1}$ Silt; $140 \mathrm{~g} \mathrm{~kg}^{-1}$ Sand and 6\% organic matter) in soil with preserved structure, using volumetric rings. These samples were then saturated using pure distilled water and a solution containing hydroplan-EB / HyA, hydroplan-EB / HyB, hydroplan-EB / HyC polymers for 24 hours (Figure I). The use of distilled water aimed to prevent possible changes in polymer behavior because of the presence of cationic and anionic ions commonly found in tap water.

Figure I. Soil saturated using distilled water (1), and HyA (2), HyB (3), HyC (4) polymers.
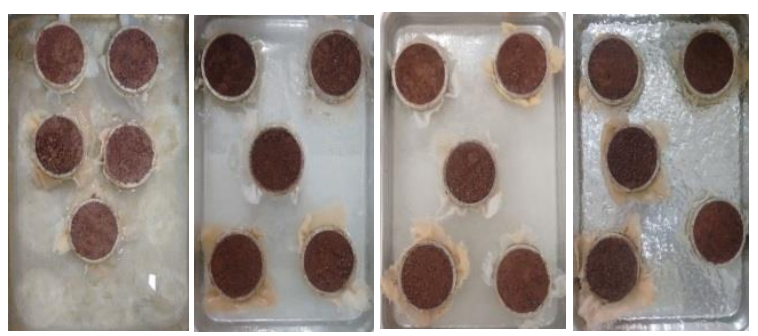

The dilution of the polymer was done using the Hamilton Beach agitator, following the recommendations for application in the coffee culture: $2 \mathrm{~g}$ of the product in $1 \mathrm{~L}$ of distilled water. The physical characterization of these polymers is in Table I. 
Table I. Physical characteristics of the polymers.

\begin{tabular}{|c|c|c|c|}
\hline Characteristics & $\mathrm{HyA}$ & $\mathrm{HyB}$ & $\mathrm{HyC}$ \\
\hline Appearance: & White granules & Fine white powder & Fine white powder \\
\hline Particle Size: & $0.5-3 \mathrm{~mm}$ & $<1 \mathrm{~mm}$ & $<0.5 \mathrm{~mm}$ \\
\hline Ionic Characteristic: & Anionic & Anionic & Anionic \\
\hline Density $\left(\mathrm{g} / \mathrm{cm}^{3}\right)$ : & 0.8 & 0.8 & 0.8 \\
\hline Solubility: & Water-insoluble & Water-insoluble & Water-insoluble \\
\hline
\end{tabular}

After saturation, the samples were subjected to matric potentials $-2,-4,-6$ and $-10 \mathrm{kPa}$ in the suction units and the matric potentials of -33 , $-100,-500$ and $-1500 \mathrm{kPa}$ in Richards extractor.

After samples stabilization at each potential, their weights were measured and the amount of water retained was determined (volumetric water content). The data were then adjusted using the van Genuchten (1980) equation, according to Equation I, adopting of Mualen (1976) $\mathrm{m}=1-1 / \mathrm{n}$, and the program SWRC (DOURADO NETO et al., 2001) to determine the model fitting parameters $(\alpha, m$ and $n)$.

$$
\begin{gathered}
\theta=\theta \mathrm{r}+(\theta \mathrm{s}-\theta \mathrm{r}) /\left[1+\left(\alpha \Psi_{\mathrm{m}}\right)^{\mathrm{n}}\right]^{1-1 / \mathrm{n}} \\
(\text { Equation } \mathrm{I})
\end{gathered}
$$

Where: $\boldsymbol{\theta}$ is the soil volumetric water content $\left(\mathrm{m}^{3} \mathrm{~m}^{-}\right.$ 3); $\Psi_{\mathrm{m}}$ is the matric potential modulus or the water tension in the ground $(\mathrm{kPa}) ; \boldsymbol{\theta} \mathbf{s}$ is the volumetric water content in the saturated sample $\left(\mathrm{m}^{3} \mathrm{~m}^{-3}\right) ; \theta \mathbf{r}$ is the volumetric water content $\left(\mathrm{m}^{3} \mathrm{~m}^{-3}\right)$ at the matric potential $-1500 \mathrm{kPa} ; \mathrm{n}$ and $\alpha$ are model fitting parameters.

After the curve obtainment, pore distribution was quantified by size using the equation proposed by Bouma (1973);

$$
\mathrm{D}=\underset{(\text { Equation II) }}{4 \sigma \operatorname{Cos} \theta / \Psi \mathrm{m}}
$$

Where: $\mathrm{D}$ is the pore diameter $(\mathrm{mm})$; $\boldsymbol{\sigma}$ is the water surface tension $\left(73.3 \mathrm{kPa} \mathrm{mm}\right.$ at $\left.20^{\circ} \mathrm{C}\right) ; \boldsymbol{\theta}$ is the contact angle between the meniscus and the tube capillary wall (considered as 0 ) and $\boldsymbol{\Psi} \mathbf{m}$ is the matric potential of the soil water $(\mathrm{kPa})$. The total porosity was considered to be moisture saturation; micro porosity was considered as moisture obtained at the potential of $-6 \mathrm{kPa}$, and macro porosity was obtained by calculating the difference between total porosity and micro porosity (EMBRAPA, 2011).

Statistical analysis was performed following a completely randomized design with 4 treatments (distilled water, $\mathrm{HyA} / \mathrm{HyB} / \mathrm{HyC}$ polymers) and five replicates. The data were subjected to variance analysis, and when significant, the comparisons of average, using the Scott-Knott test at $5 \%$ significance was conducted through the Sisvar statistical program (FERREIRA, 2011).

\section{RESULTS AND DISCUSSION}

The water retention curves adjusted for the soil saturated with distilled water and three polymers are show in the figure II and model adjustment parameters in table II.

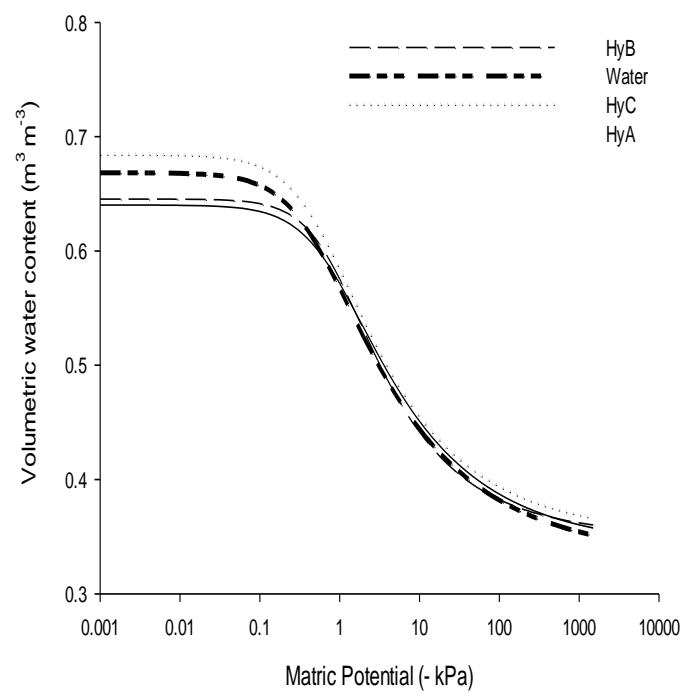

Figure II. Water retention curve [amount of water in the soil $\left(\mathrm{m}^{3} \mathrm{~m}^{-3}\right)$ due to matric potential $\left.(\mathrm{kPa})\right]$ adjusted by the van Genuchten (1980) model for a Latosol saturated with pure water and polymers. 
Table II. Empirical parameters from the van Genuchten (1980) equation adjustment ( $\alpha$ e n), water content at saturation $(\theta \mathrm{s})$,residual water content $(\theta \mathrm{res})$, volumetric water content at the inflection point $(\theta \mathrm{pi})$, and the matric potential at the inflection point of the retention curve ( $\Psi \mathrm{mpi})$.

\begin{tabular}{ccccccc}
\hline \multirow{2}{*}{ Treatment } & $\mathrm{n}$ & $\alpha$ & $\theta$ sat & $\theta$ res & $\theta$ pi & $\Psi$ mpi \\
\cline { 2 - 7 } & & & $-----------\mathrm{m}^{3} \mathrm{~m}^{-3}----------$ & $\mathrm{kPa}$ \\
Water & 1.355 & 2.32 & 0.66 & 0.33 & 0.54 & 1.236 \\
HyA & 1.380 & 1.46 & 0.64 & 0.34 & 0.52 & 1.899 \\
HyB & 1.474 & 1.22 & 0.64 & 0.35 & 0.52 & 1.815 \\
HyC & 1.394 & 2.18 & 0.68 & 0.35 & 0.55 & 1.373 \\
\hline
\end{tabular}

Visually it can be seen that the soil saturated with the $\mathrm{HyC}$ polymer has the highest water content (Figure II), from saturation $(\theta \mathrm{s})$ until the residual water content $\left(=\theta \mathrm{r} 0.35 \mathrm{~m}^{3} \mathrm{~m}^{-3}\right)$.

Oliveira et al. (2004a) evaluated the influence of different concentrations of a polymer on water retention of a Red-Yellow Latosol, with medium texture, and cambic clayey Red-Yellow Argisol, and found that for matric potentials up to $1000 \mathrm{kPa}$, the water retention increased as the polymer concentration in the soil increased, however, for lower matric potentials (more negative), water retention was not influenced by the concentration of the product, which would indicate that its effect would occur in large and mediumsized pores, called structural pores, according to the classification adopted by Carducci et al. (2011).

In sandy soils, the results found by Varennes et al. (1997) were a little different because they found that with the increase of the polymer addition to the soil, a linear increase was obtained in soil water retention in the range from -0.01 to -1500 $\mathrm{kPa}$.

It can be noted in Figure II that for less negative matric potentials ( 0 to $-1 \mathrm{kPa}$ ), soil treated using HyA e HyB polymers apparently retains less water content than the soil saturated with only water (Figure II). Visually, in this range of matric potential, soil water retention increases in the following order: $\mathrm{HyC}>$ Water $>\mathrm{HyB}>\mathrm{HyA}$. This water retention sequence at the least negative potentials could be related to polymer particle size, since it was observed that under the conditions of this study, the lower the polymer particle size (Table I), the higher its water retention capacity. This is probably due to the higher specific surface area conditioned by the smaller-sized particles (BARBOSA et al., 2014), however this is an issue that needs to be better explored.

The soil water retention curve behavior using $\mathrm{HyC}$ polymer indicated that this product can enhance the soil in its operation as a water reservoir, because it retains more water at less negative matric potentials and this could minimize water losses via gravity (BARBOSA et al., 2014, CARDUCCI et al., 2015).

It can be noted that in this study doses of the products have not been tested or studied with plants. Therefore, the potential of the HyC polymer needs to be further studied. However, if it is confirmed that this polymer, in higher doses, can significantly increase the water retention in the soil, this would be an alternative for the more efficient use of ground water, or even for reducing irrigation rates, thus being an alternative for the more rational use of water resources.

In agriculture, some works, such as Marques et al. (2013), have suggested that the hydrogel may be an alternative to heavy irrigation. These authors evaluated the performance of seedlings of 'Iapar 59' coffee and concluded that the use of hydroplan-EB $\AA$ polymer at a dose of $2 \mathrm{~g}$ per seedling bag, was very efficient. Azevedo et al. (2002), studying the efficiency of hydrogel added in planting substrate of 'Tupi' coffee seedlings, observed that the presence of hydrogel allowed to extend the intervals between irrigations without compromising plant growth.

Observing Table III, statistical analysis shows that there are no significant differences for the variables macro porosity, micro porosity and total pore volume. 
Table III. Soil porosity right after soil saturation using water and polymer.

\begin{tabular}{cccc}
\hline Treatment & Macro & Micro & TP \\
& & & \\
Water & $0.20 \mathrm{a}$ & $0.46 \mathrm{a}$ & $0.66 \mathrm{a}$ \\
$\mathrm{HyA}$ & $0.16 \mathrm{a}$ & $0.48 \mathrm{a}$ & $0.64 \mathrm{a}$ \\
$\mathrm{HyB}$ & $0.18 \mathrm{a}$ & $0.46 \mathrm{a}$ & $0.64 \mathrm{a}$ \\
$\mathrm{HyC}$ & $0.20 \mathrm{a}$ & $0.48 \mathrm{a}$ & $0.68 \mathrm{a}$ \\
\hline
\end{tabular}

Averages followed by the same letter in the column do not differ by the Scott-Knott test $5 \%$.

The use of polymers HyA and $\mathrm{HyB}$ decreases pores volume of size class greater 145 micrometers (Table IV). It can be noted that large macro pores are related to high hydraulic conductivity (OLIVEIRA et al., 2004b), this means that are pores responsible for the rapid soil draining and therefore play an important environmental role being responsible for groundwater recharge (CARDUCCI et al., 2015).
Using HyB polymers, besides the significant reduction in the volume of pores $>$ 145 micrometers size class, there was a reduction in the pore volume of the classes from 2.9 to 0.6 and from 0.6 to 0.2 micrometers. This is the most worrying result, since these are considered intermediate pores, and are responsible mainly for providing water to the plants (CARDUCCI et al., 2011, CARDUCCI et al., 2015), when the goal of the product is the increase in the availability of water to plants.

Table IV. Pore Size Distribution in a saturated Latosol with water and polymers.

\begin{tabular}{|c|c|c|c|c|}
\hline Pore Diameter Classes & Water & HyB & НyА & HyC \\
\hline ----------( $(\mu \mathrm{m})$--------- & \multicolumn{4}{|c|}{-Pore Volume $\left(\mathrm{m}^{3} \mathrm{~m}^{-3}\right)$} \\
\hline$>145$ & $0.143 \mathrm{a}$ & $0.114 \mathrm{~b}$ & $0.108 \mathrm{~b}$ & $0.145 \mathrm{a}$ \\
\hline $145-73$ & $0.039 \mathrm{a}$ & $0.043 \mathrm{a}$ & $0.039 \mathrm{a}$ & $0.041 \mathrm{a}$ \\
\hline $73.43-49$ & $0.019 \mathrm{a}$ & $0.022 \mathrm{a}$ & $0.020 \mathrm{a}$ & $0.020 \mathrm{a}$ \\
\hline $49-29$ & $0.021 \mathrm{a}$ & $0.023 \mathrm{a}$ & $0.023 \mathrm{a}$ & $0.023 \mathrm{a}$ \\
\hline $29-9.0$ & $0.038 \mathrm{a}$ & $0.038 \mathrm{a}$ & $0.04 \mathrm{a}$ & $0.038 \mathrm{a}$ \\
\hline $9.0-2.9$ & $0.024 \mathrm{a}$ & $0.021 \mathrm{a}$ & $0.024 \mathrm{a}$ & $0.023 \mathrm{a}$ \\
\hline $2.9-0.6$ & $0.021 \mathrm{a}$ & $0.016 \mathrm{~b}$ & $0.021 \mathrm{a}$ & $0.019 \mathrm{a}$ \\
\hline $0.6-0.2$ & $0.028 \mathrm{a}$ & $0.014 \mathrm{~b}$ & $0.025 \mathrm{a}$ & $0.023 \mathrm{a}$ \\
\hline$<0.2$ & $0.331 \mathrm{a}$ & $0.351 \mathrm{a}$ & $0.341 \mathrm{a}$ & $0.351 \mathrm{a}$ \\
\hline
\end{tabular}

Averages followed by the same letter in the line do not differ by the Scott-Knott test $5 \%$. 


\section{CONCLUSIONS}

For the Clayey Latosol studied the $\mathrm{HyB}$ polymer promoted significant, but negative changes, by reducing the volume of pores with an average diameter, responsible for the rapid availability of water for plants.

\section{REFERENCES}

ALBUQUERQUE FILHO, J. A. C.; LIMA, V. L. A.; MENEZES, D.; AZEVEDO, C. A. V.; DANTAS NETO, J.; SILVA JUNIOR, J. G. Características vegetativas do coentro submetido a doses do polímero hidroabsorvente e lâminas de irrigação. Revista Brasileira de Engenharia Agrícola e Ambiental, v. 13, p. 671679, 2009.

ARAUJO JUNIOR, C. F.; DIAS JUNIOR, M. S.; GUIMARÃES , P. T. G.; ALCÂNTARA, E. M. Sistema poroso e capacidade de retenção de água em Latossolo submetido a diferentes manejos de plantas invasoras em uma lavoura cafeeira. Planta Daninha, v.29, p. 499-513, 2011.

AZEVEDO, T. L. F.; BERTONHA, A.; GONÇALVES, A. C. A. Uso de hidrogel na agricultura. Revista do programa de Ciências Agro-Ambientais, v. 1, p. 23-31, 2002.

BARBOSA, S. M.; OLIVEIRA, G. C.; CARDUCCI, C. E.; SILVA, B. M. Potencialidade de uso de zeólitas na atenuação do déficit hídrico em Latossolo do cerrado. Semina: Ciências Agrárias, v. 35, p. 2357-2368, 2014.

BOUMA, J. Guide to the study of water movement in soilpedons above the watertable. Madison: University of Wisconsin, p.194, 1973.

CARDUCCI, C. E.; OLIVEIRA, G. C.; OLIVEIRA, L. M.; BARBOSA, S. M.; SILVA, E. A. Retenção de água do solo sob sistema conservacionista de manejo com diferentes doses de gesso. Revista de Ciências Agrárias, v. 58, p. 284-291, 2015.
CARDUCCI, C. E.; OLIVEIRA, G. C.; SEVERIANO, E. C.; ZEVIANI, W. M. Modelagem da curva de retenção de água de Latossolos utilizando a equação duplo van Genuchten. Revista Brasileira de Ciência do Solo, v. 35, p. 77-86, 2011.

CASTRO, A. M. C.; MAIA, G. M.; SOUZA, J. A.; MANFIO, F. L. A. Crescimento inicial de cafeeiro com uso de polímero hidrorretentor e diferentes intervalos de rega. Coffee Science, v. 9, p. 465- 471, 2014.

DEMARTELAERE, A. C. F.; DUTRA, I.; ALVES, S. S. V.; TEÓFILO, T. M. S.; ALVES, S. V. Utilização de polímero hidroabsorvente no meloeiro (Cucumis melon L.) sob diferentes lâminas de irrigação. Revista Caatinga, v. 22, p. 5-8, 2009.

DOURADO NETO, D.; NIELSEN, D. R.; HOPMANS, J. W.; REICHARDT, K.; BACCHI, O. O. S.; LOPES, P. P. Soil water retention curve. SWRC, version 3.00 . Piracicaba, 2001.

EMBRAPA - Empresa Brasileira de Pesquisa Agropecuária. Embrapa Solos. Manual de métodos de análises de solo. 2. ed, Rio de Janeiro. 230 p, 2011.

EMBRAPA - Empresa Brasileira de Pesquisa Agropecuária. Embrapa Solos. Sistema brasileiro de classificação de solos. 3. ed. Brasília. 353 p, 2013.

FERREIRA, D. F. SISVAR 5.0. Sisvar: a computer statistical analysis system. Ciência e Agrotecnologia, v. 35, p. 1039-1042, 2011.

HORTON, R.; THOMPSON, M. L.; MCBRIDE, J. F. Method of estimating the travel time of noninteracting solutes through compacted soil material. Soil Science Society of America Journal, v. 51, p. 48-53, 1987.

LOPES, J. A. W.; SILVA, M. R.; SAAD, J. C. C.; ANGÉliCO, T. S. Uso de hidrogel na sobrevivência de mudas de Eucalyptus urograndis produzidas com diferentes substratos e manejos hídricos. Ciência Florestal, v. 20, p. 217-224, 2010.

MARQUES, P. A. A.; BASTOS, R. O. Uso de diferentes doses de hidrogel para produção de mudas de pimentão. Pesquisa Aplicada \& Agrotecnologia, v. 3, p. 53-57, 2010. 
MARQUES, P. A. A.; CRIPA, M. A. M.; MARTINEZ, E. H. Hidrogel como substituto da irrigação complementar em viveiro telado de mudas de cafeeiro. Ciência Rural, v. 43, p. 1-7, 2013.

MUALEM, Y. A new model for predicting the hydraulic conductivity of unsaturated porous media. Water Resources Research, v. 12, p. 513 522, 1976.

OLIVEIRA, R. A.; REZENDE, L. S.; MARTINEZ, M. A.; MIRANDA, G. V. Influência de um polímero hidroabsorvente sobre a retenção de água no solo. Revista Brasileira de Engenharia Agrícola e Ambiental, v. 8 , p. $160-163,2004 a$.

OLIVEIRA, G. C.; DIAS JUNIOR, M. S.; RESCK, D. V. S.; CURI, N. Caracterização química e físico-hídrica de um Latossolo Vermelho após vinte anos de Manejo e cultivo do solo. Revista Brasileira de Ciência do Solo, v. 28, p. 327-336, 2004b.

PREVEDELLO, C. L.; BALENA, S. P. Efeitos de polímeros hidrofílicos nas propriedades físico hídricas de dois meios porosos. Revista Brasileira de Ciência do Solo, v. 24, n. 2, p. 251258, 2000 .

SANTOS, H. T.; CARVALHO, D. F.; SOUZA, C. F.; MEDICI, L. O. Cultivo de alface em solos com hidrogel utilizando irrigação automatizada. Engenharia Agrícola, v. 35, p. 852-862, 2015.

SILVA, B. M.; SILVA, E. A.; OLIVEIRA, G. C.; FERREIRA, M. M.; SERAFIM, M. E. Plantavailable soil water capacity: Estimation methods and implications. Revista Brasileira de Ciência do Solo, v. 38, p. 464-475, 2014.

SILVA, B. M.; OLIVEIRA, G. C.; SERAFIM, M. S.; SILVA, E. A.; FERREIRA, M. M.; NORTON, L. D.; CURI, N. Critical soil moisture range for a coffee crop in an oxidic Latosol as affected by soil management. Soil Tillage Research, v. 154, p. 103-113, 2015.

van GENUCHTEN, M. T. A. A closed-form equation for predicting the hydraulic conductivity of unsaturated soils. Soil Science Society of America Journal, v. 44, p. 892-898, 1980.
VARENNES, A.; BALSINHAS, A.; CARQUEJA, M. J. Effects of two na polyacrylate polymers on the hydrophysical and chemical properties of a sandy soil, and on plant growth and water economy. Revista de Ciências Agrárias, v. 4, p. 13-27, 1997.

ZONTA, J. H.; BRAUN, H.; REIS, E. F.; PAULUCIO, D.; ZONTA, J. B. Influência de diferentes turnos de rega e doses de hidroabsorvente no desenvolvimento inicial da cultura do café conillon (Coffea canephora Pierre). Idesia, v. 27, p. 29-34, 2009. 